DOI: $10.22616 /$ REEP.2020.040

\title{
Challenges of Sustainable Development for Children in Kinship Care Families
}

\author{
Aiga Romāne-Meiere Mg.soc.d. \\ University of Latvia, Latvia \\ aiga.romane-meiere@lu.lv
}

\begin{abstract}
Children taken out of biological families can be placed in kinship care, foster families or in institutions. International and national political documents determine that placement close to family is a basic priority. On the other hand, kinship care families experience multiple risk factors with impact on the child sustainable development. The aim of the study is to identify resilience factors in kinship care families. To identify resilience factors in kinship families multiple case study methodology is used. There are 3 general cases - grandparents kinship families, other relative kinship families and non-relative kinship families. In order to explore selected sub-cases and its broader context participant observation in six support groups observation in four summer camps, unstructured in-depth interviews with 16 kinship family members, and posts in social networks are used. The analysis shows that main factors can be divided in levels starting from individual traits and communication with biological parents to cooperation with institutions and juridical legislation. Resilience factors differ in each sub-case in such aspects as generational gap or similarity, common identity and experience, belonging, cooperation with institutions. To attain sustainable development for children in kinship care families support for each caregivers group should be differenced.
\end{abstract}

Keywords: sustainable development, kinship care, resilience factors.

\section{Introduction}

The National Development Plan 2014-2020 is related to the Sustainable Development Strategy of Latvia until 2030 (National Development Plan..., 2012). A Vision of Latvia in 2020 defines that parents have become active and responsible participants in the educational process and children left without parental care are taken in by trustworthy and responsible families. Kinship care is a domestic or living arrangement in which a biological family member or fictive kin (a non-biological relative with a strong emotional tie to a child) assumes care for a child (Denby, 2016). The concept of kinship care is used in different versions - kinship care (USA, New Zealand), kin and kin care (Australia), relative care (Ireland), family and friends care (UK) or relative foster care (Sweden, Norway) (O’Brien, 2012; Winokur, Holtan, Batchelder, 2014). In all used terms it is understandable that it means care of child in family placement with relatives or close friends.

If child is taken out of biological family there are three child care forms possible - kinship care, foster families and institutional care. There are powerful traditions of kinship care from soviet times in Latvia. Civil law defines that "a child's guardian is a person appointed to protect the rights and interests of a child left without parental care. The guardian substitutes for the child's parents and represents the child's personal and property interests" (The Civil Law, 1937). Kinship or guardianship is still the oldest and largest form of child care. The largest part - $66 \%$ of children live in kinship care families, $17,5 \%$ in foster families and $15,5 \%$ in institutional care (Pārskats par lietām..., 2018). It is declared that every child has rights to grow up in family. It means that kinship care should be accepted as a resource used within the child welfare system during process of deinstitutionalization. Even more, international political document UN Convention on the Rights of the Child (Convention on the Rights..., 1989) determine that child care in environment close to family is a basic priority (Green, Goodman, 2010, 1358; Nandy, Selwyn, 2011, 4).

A child can be placed in kinship families in cases when biological parents are died or because of addictions, physical or emotional abuse, neglection of child, mental illnesses of parents or parents are under-age. Mentioned problems are complex, connected with dysfunctional roots in extended family system and connected with child welfare system in Latvia.

Most of available researches provide evidence of advantages of kinship care - improved safety for child, stability, increased sense of belonging and connection, greater social and emotional well-being (Denby, 2016; Winokur, Holtan, Batchelder, 2014). Despite advantages kinship caregivers tend to be older, less educated, of poorer physical health (Messing, 2006), at the same time having fewer resources and 
support than non-relative foster families (Lin, 2014, 35) what can result as a kinship breakdown (Parolini et al., 2018) and negative impact on child development.

Theoretical framework used to analyse process of identifying risk and protective factors in kinship families is the theory of resilience in eco-systemic perspective. Poetically can be said that "resilience is the science of mastering life's greatest challenges" (Southwick, Charney, 2012). In recent years number of definitions of resilience has been developed. One of theoretical framework is M. Ungar (2008) social ecological interpretation of resilience what defines resilience in broader way "In the context of exposure to significant adversity, resilience is both the capacity of individuals to navigate their way to the psychological, social, cultural, and physical resources that sustain their well-being, and their capacity individually and collectively to negotiate for these resources to be provided and experienced in culturally meaningful ways". Understood this way, resilience is the qualities of both the individual and the individual's environment that potentiate positive development (Ungar, Liebenberg, 2011). Resilience arises from researches that aims to understand healthy and sustainable development or positive adaptation despite adverse conditions more commonly associated with negative outcomes (Bottrell, 2009). Resilience can be understood as a personal trait, process or as a result (Collins, 2016; Rutter, 2012; Van Breda, 2018). In eco-systemic framework, professor of social work M. Ungar (2011) explains that resilience results from a cluster of ecological factors that predict positive human development more than individual traits, and that the effect of an individual's capacity to cope and the resources he or she has is influenced by the nature of the challenges the individual face (Ungar, 2011, 14). This definition leads to broader understanding of influential factors in kinship families. Criteria of assessment of positive or mal-adaptation is embedded in socio- cultural assumptions and historically specific societal expectations (Bottrell, 2009). Social policy and social environments have a significant role in eco-systemic perspective (Ungar, 2008; Yıldırım, Hablemitoğlu, 2013).

The social profile of kinship caregivers and traumatic experience of child taken in care or trauma in a whole extended family system include certain risk factors in individual or family system level while social policy, economical situation, traditions and public discourses are source of contextual factors. The aim of the study is to identify resilience factors in kinship care families with influence on sustainable development of a child.

\section{Methodology}

Traditionally in qualitative research case study designs are particularly suited to situations involving a small number of cases with a large number of variables, for example, resilience factors in three subcases. The approach is appropriate for the investigation of cases when it is necessary to understand parts of a case within a context of the whole (De Vaus, 2001, 231; Yin, 1993). Selected cases must be seen and analysed within the context. Resilience factors in kinship care families are interconnected with child welfare system in Latvia. "By examining this context fully, the researcher can gain a fuller and rounder picture of the causal processes surrounding a particular phenomenon" (De Vaus, 2001, 235).

To identify resilience factors in kinship families multiple - case study design is used with tree theoretically different sub-cases. Sub-cases are strategically selected according to already existing division in Latvia what is based on relationship with a child in care 1) grandparent kinship care, 2) other relative kinship care, 3) non-relative kinship care.

There were three criteria to involve family in research. First, care is formally established with official decision. Second, families in each sub-case had specific differences (lives in city or in rural areas, ethnic differences, gender differences, age of caregivers and age of child in care). Third, informed agreement what includes possibility to refuse participation in any stage of research is signed.

Case studies are done parallel from February 2018 and incorporate a context and a retrospective time dimension. Reconstruction of the past in the light of the present (De Vaus,2001, 228), family's history cannot be escaped because kinship care is consequences of traumatic processes in biological family of a child and past experience influence on resilience of family.

Typically, different kind of methods of data collections can be used within case studies. In order to explore selected sub-cases and its broader context participant observation in six support groups and 
observation in four summer camps, unstructured in-depth interviews with 16 kinship family members and posts in social networks are used.

Observation was possible in six support groups of kinship caregivers (average number of participants is 6 , organised in Riga, led by social worker, each participant informed about confidentiality nuances). Influential factors were observed in four summer camps where approximately 50 families gathered and during interviews. Unstructured in-depth interviews were conducted with 16 family members from different sub-cases -9 care givers and 7 children living in kinship care (older than 12 years). Two of kinship caregivers were male, six of them living in small villages, three caregivers were under 65 , two speaking only in Russian. Specific differences allow to explore complexity of kinship families. Children and care givers posts in social networks were used only in situations when it was accepted from authors. Multiple source of evidence is a major strength of case studies. To analyse influential resilience factors in each sub-case data triangulation and data content analyse was used.

During gathering data special attention was paid to ethical nuances. No data is worth it if there are risks to make situation more painful or difficult for participant. Stories in interview include traumatic experience in biological family and difficulties in kinship families. Participants were informed that they decision to withdraw from research in any stage will be respected. Researcher caused dynamic changes of whole family system and results of the research as well. For example, to understand better capacity to recover quickly from difficulties there were defined some questions: "What do you see in future?", "Which person can inspire you in difficult moments?", "Can you describe the place where do you feel the most powerful?"

Research questions 1) what are tendencies of alternative care in Latvian context, 2) what risk factors and protective factors influence resilience in kinship care families, 3) what is the interaction among identified factors, 4) what are differences in grandparent's kinship families, other relative kinship families and non-relative kinship families?

\section{Results and Discussion}

Traumatic events throw our lives into turmoil in unpredictable ways; two people will not respond to them in exactly the same manner (Southwick, Charney, 2012). Some social groups are more liable to misfortunes and confronted with threats and significant sources of stress. Statistics, observations and process of study confirm that in Latvia kinship caregivers is vulnerable social group.

There should be kept in both - in researcher and social work mind that "resilience and family resilience perspective is grounded in deep conviction of potential of all families to gain positive growth out of adversity, even those who have experienced severe trauma or very troubled relationships can forge healing and transformation across the life course and the generations" (Walsh, 2016, 18). Usage of language and used questions is powerful part of qualitative research. On resilience theory-based communication, when researcher is truly interested in potential, moments of success, resources and strengths, can encourage caregivers to share their stories more honestly.

In case studies great varieties of resilience factors were recognised with some similarities in all subcases and some specific factors in different case. Factors relevant to sustainable development of children in each case are divides in personal level, family system level and community level (Table 1).

In all studied sub-cases kinship care families still experience great amount of risk factors - behavioural problems of child, unsolved puzzle of trauma, poverty, conflicting relationships into the family system, especially with biological parents of a child, lack of social support and information about rights, frustrations caused by threats of control from institutions, feeling of discrimination compering to foster families. Identified risk factors confirm concerns of limits of sustainable development for children in kinship care. Risks are connected with traumatic experience in family system. Life stories from kinship family members contain situations with sexual and physical violence, alcohol or drug addictions in the past, or in some cases it still continues. 
Resilience factors in kinship care families

\begin{tabular}{|c|c|c|}
\hline Grandparents families & Relatives families & Non-relatives families \\
\hline $\begin{array}{l}\text { Attachment } \\
\text { Difficulties to manage rules } \\
\text { Overprotection } \\
\text { Destructive emotions } \\
\text { Financial problems, poverty } \\
\text { Behavioural problems of child } \\
\text { Generational gap } \\
\text { Differences in digital skills }\end{array}$ & $\begin{array}{l}\text { Common identity Responsibility } \\
\text { Realistic expectations }\end{array}$ & $\begin{array}{l}\text { Feeling of mission } \\
\text { Tendency to change identity of } \\
\text { child } \\
\text { Optimistic view on future } \\
\text { High level of expectations } \\
\text { Unclear motivation }\end{array}$ \\
\hline $\begin{array}{l}\text { Belonging to family system } \\
\text { Conflicts with biological parents } \\
\text { Common memories, traditions } \\
\text { (positive and negative) } \\
\text { Difficulties to manage } \\
\text { communication with biological } \\
\text { parents }\end{array}$ & $\begin{array}{l}\text { Belonging to family system } \\
\text { Unclear roles } \\
\text { Common memories, traditions } \\
\text { Challenges to manage personal } \\
\text { life }\end{array}$ & $\begin{array}{l}\text { Tendency to minimize contact } \\
\text { with biological parents } \\
\text { Ignorance to feelings of loss } \\
\text { Possibility to develop new } \\
\text { traditions } \\
\text { Comparison with biological } \\
\text { parents }\end{array}$ \\
\hline $\begin{array}{l}\text { Lack of social support and training } \\
\text { Shame, tendency to hide problems } \\
\text { from society and institutions }\end{array}$ & $\begin{array}{l}\text { Pressure from society } \\
\text { Lack of training about child needs } \\
\text { Cooperation with institution }\end{array}$ & $\begin{array}{l}\text { Avoidance of cooperation with } \\
\text { institutions } \\
\text { Lack of training and social support }\end{array}$ \\
\hline
\end{tabular}

Harmful memories can cause dynamic in family system. There are aspects in family history what contain essential information to understand causality in kinship families, at the same time researcher has responsibility to minimize potential risks to make situation less dysfunctional. For example, sexual violence happened ten years ago, but memories of that period can arise again the same feelings and emotions.

\section{Grandparents kinship care}

As population age rapidly, intergenerational family relations become more and grandparent's investment include different types of support (Tanskanen, Danielsbacka, 2019). Grandparents may increase children`s wellbeing during risks situations, including parental death, divorces (Carlson et al., 2014). If child is taken out from biological family with decision of custody court, it means support from grandparent or other relatives were not sufficient. Dysfunctional roots can be developed through generations.

In the cases when child was raised by grandparents there were exposed such emotions as guilty for adversities in past, anxiety, fears from future, fears from institutions, anger to biological parents what are risk factors for child development and hope, attachment, forgiveness, willingness to resolve mistakes as a protective factor. Compering grandparents, other relatives and non-relative kinship families, in grandparents' family's emotions were identified as more important factor. In grandparents' families main issues are unsolved conflicts with biological parents if they are alive. Child can be used as mediator in conflicting triangle. There are difficulties to protect child from abusive parents, sometimes all three generations are still living in the same apartment. Unsecure family environment has negative impact on development of child in care. Problems raise low level of living conditions, poverty, and low level of education of care giver. In that situation education and wellbeing can have minimized or exaggerated value.

Position of neutral "outsider" can provoke willing maintain an 'empathic distance' and 'absence of language sensitivity' (Berger, 2015). It is always an important question which person is called a father or mother in kinship care family. What term should be used during interviews? Especially, if there are cases when child is not informed that caregiver is not his biological parent. It can be confusing for a child and cause strong dynamic in further relationship if during the first interview guardian or kinship caregiver is called "mother". Grandparents have possibility to perform role of parents, but in cases when story about biological parents is kept in secret for a child, and caregivers pretend to be a biological parent, it is an important risk factor for sustainable development.

Generational gap is directly connected with differences according to social norms and digital skills. It is impossible to image educational process without usage of technologies nowadays. The contemporary family is progressively a network family, adopting a variety of digital technologies to coordinate their lives, 
to be connected throughout the day, and to bond and share moments online (Casimiro, Nico, 2018). If grandparents do not use internet and social networks it makes limits in communication - part of information of child in care is not available. Phone calls are mostly used to get information about educational success.

\section{Other relatives kinship care}

Other relatives as caregivers can be described as more resilient - their story include more positive emotions comparing to grandparents and non-relative caregivers. If brother or sister becomes a caregiver there rise difficulties to perform parental role. Person has double roles at the same time. American social work professor R. Denby has highlighted brothers and sisters as a special group of caregivers with special needs of support (Denby, 2016), because in that case child and care parson has the same generation. They share the same relations towards biological parents who were not able to continue their parental duties. They have similar traumatic experience what causes belongingness. Deep connection strengthens well known dysfunctional patterns. Professional support develops skills to manage every day routine in a way that fosters sustainable development of a child in care.

Aunts and uncles usually have their own nuclear families already. Pressure from society causes the decision to become a caregiver even it has negative consequences to their family functionality. On the other hand, aunts and uncles have distance from dysfunctional family system and it is easier to build new patterns of behaving and connections.

\section{Non-relative kinship care}

Statistics explain that half of non-relative caregivers were known persons for a child before. These persons can be neighbours, friends, teachers. In these cases, resilience factors are similar to other relatives. Motivation of persons not known for child before are still raises concerns. There is possibility to become a foster family with more adequate financial and social support, regular training.

Non-relative caregivers tend to protect privacy, avoid cooperation with institutions - social services, custody court, what recalls that there is not biological ties between parents and children. There is a risk of safety of a child.

In all cases kinship caregivers spoked about frustration according to control - felling of evaluation all the time. Frustrations connected with control and possibility that child can be taken out of kinship family, minimize chances to receive necessary social support:

"Professionals from child welfare system once decided that I am able to take care for a child. Actually, we don't have other options for placement or other relatives. But every year child has to answer to the same question - do you still want to live with your caregiver? And if we will really have serious problems - what will happen then? It is threatening situation. I always carefully think what I tell to other people."

In this example to maintain stability and minimize confusion caused by child care system caregivers use strategy of secrecy.

In all regions support groups for kinship caregivers formally should be organised in Latvia. Interviewed caregivers have no information about them. Group support can be important protective factor to maintain resilience, but interviews show that none of caregivers have attended them before, because caregivers have interpreted participating in these groups as a risk factor for their safety

Social networks are often mentioned in theoretical literature as important protective factor. "Linkages with the social world are vitally important for family resilience. Networks helpfulness depends on the quality of the relationships. Some are better with practical assistance, others with emotional support" (Walsh, 2016, 77). Networks should provide sense of belonging, security and solidarity. Unfortunately, kinship caregivers in Latvia are reserved towards networking. Effective social work in community can create trustful networks that lead to individual resilience, family resilience and resilience of social group. Blaming grandparents who are kinship caregiver for their insufficient parental competences is dominant attitude in public discourse in Latvia. Quite often representatives from institutions repeat this dominant attitude. Grandparents are blamed for prolonged dysfunction in family system. Social context promotes vulnerability of caregivers that should be kept in mind during field work. 
In all cases as a risk factor was mentioned sense of inequality comparing with foster families in such categories as social support, educational trainings and financial support. Trainings to develop parental competences before child is placed in family are available only for foster parents, financial support for foster families is approximately three times larger. The social support is possible only if problems arise but then there is doubts "Am I good enough to continue to take care for a child?" Kinship caregivers feel discriminated compared to foster families:

"We do the same job. We take care for children whose parents are not able to do it. Our children have the same needs. So, why foster families have such a support - materially, financially, social services, summer camps for children, appreciative attitude? While we (kinship families) are still ignored."

\section{Conclusions}

Resilience factors are visible when adversity or risk factors are present and there are concerns about sustainable development of a child. In case of kinship care families, part of risks comes from experience in biological family - addictions, sexual and physical abuse, neglection, mental or other illnesses, and death of biological parent. Despite traumatic events that in some cases still continue, family system is searching strategies to function. Every family has different risk factors and protective factors. In kinship care sub-cases similarities and differences were found.

Kinship families have complex family structure where relationships are conflicting, confusions of parental responsibilities, especially in cases if biological parents are nearby in community. Most of identified factors can be risk factors and protective factors for family system, depending on concrete context. Variations of interaction of influence factors can be observed. In grandparents' families main resilience factors are attachment, belonging to family system, common memories and traditions, minimized feeling of loss. In relatives' families resilience can be built from common identity, responsibility, realistic expectations, belonging, common memories, and cooperation with institution. Non-relative families have feeling of mission, optimistic view on future, higher level of expectations, possibility to make new traditions. To promote sustainable development of a child support system should be flexible according to individual needs of members of family.

Kinship caregivers recognised discrimination comparing with foster families - they are lacking social services, financial support, trainings, supportive attitude from society. Actually, no non-governmental organisation exists in Latvia that works for interests of kinship caregiver. Kinship caregivers are social group without voice in social policy and media. Despite tendency to develop foster care system social campaigns in media most of children taken out of biological family are still living in kinship care. Social ignorance disempowers caregiver's ability to protect children's interests that has negative impact on further development.

\section{Bibliography}

1. Berger R. (2015). Now I see it, now I don't: researcher's position and reflexivity in qualitative research. Qualitative Research, 15(2), 219-234. doi: 10.1177/1468794112468475

2. Bottrell D. (2009). Understanding Marginal Perspectives: Towards a Social Theory of Resilience. Qualitative Social Work, 8(3),321-339. doi: 10.1177/1473325009337840

3. Carlson M.J., Meyer D.R., Dunifon R.E., Ziol-Guest K.M., Kopko K. (2014). Grandparent coresidence and family well-being: Implications for research and policy. The ANNALS of the American Academy of Political and Social Science, 654(1), 110-126. doi: 10.1177/0002716214526530

4. Casimiro C., Nico M. (2018). From object to instrument: technologies as tools for family relations and family research. In B.B. Neves, C. Casimiro (Eds.), Connnecting families? Information and Communication Technologies, generations, and the life course. Bristol: Policy Press, 133-156. doi: 10.1332/policypress/9781447339946.003.0008

5. Collins S. (2016). Social Workers and Resilience Revisited. Practise.29(2), 85-105. doi: 10.1080/09503153.2016.1229763

6. Convention on the Rights of the Child. UN General Assembly. (1989). Retrieved from https://www.refworld.org/docid/3ae6b38f0.html

7. De Vaus D. (2001). Research Design in Social Research. London: Sage. 
8. Denby R.W. (2016). Kinship care. Increasing child well-being through practise, policy, and research. New York, NY: Springer Publishing Company.

9. Green Y.R., Goodman C.C. (2010). Understanding birthparent involvement in kinship families: Influencing factors and the importance of placement arrangement. Children and Youth Services Review, 32(10), 1357-1364. doi: 10.1016/j.childyouth.2010.06.003

10. Lin C.H. (2014). Evaluating Services for Kinship Care Families: A Systematic Review. Children and Youth Services Review, 36, 32-41. doi: 10.1016/j.childyouth.2013.10.026

11. Messing J.T. (2006). From the child's perspective: A qualitative analysis of kinship care placements. Children and Youth Services Review, 28(12), 1415-1434. doi: 10.1016/j.childyouth.2006.03.001

12. Nandy S., Selwyn J. (2011). Spotlight on kinship care. University of Bristol. Retrieved from http://www.bristol.ac.uk/media-library/sites/sps/migrated/documents/execsum.pdf

13. National Development Plan of Latvia for 2014-2020. (2012). Riga: Cross-Sectoral Coordination Centre. Retrieved from https://www.pkc.gov.lv/images/NAP2020\%20dokumenti/NDP2020_English_Final.pdf

14. O'Brien V. (2012). The Benefits and Challenges of Kinship Care. Child Care in Practice18(2), 127-146. doi: 10.1080/13575279.2012.657610

15. Parolini A., Shlonsky A., Magruder J., Eastman A.L., Wulczyn F., Webster D. (2018). Age and other risk factors related to re-entry to care from kin guardian homes. Child Abuse and Neglect,79, 315-324. doi: 10.1016/j.chiabu.2018.02.024

16. Pārskats par lietām par bērna aprūpes un aizgādības tiesību atṇemšanu un atjaunošanu vecākiem [Overview of the cases of parental disqualification and restoration of parental rights]. (2018). Bāriņtiesu statistika par 2017. gadu. Retrieved from http://www.bti.gov.lv/in_site/tools/download.php?file=files/text/bt.stat_2017.pdf (in Latvian)

17. Rutter M. (2012). Resilience as a dynamic concept. Development and Psychopathology, 24(2), 335-344. doi: 10.1017/S0954579412000028

18. Southwick S.M., Charney D.S. (2012). Resilience. The Science of Mastering Life`s Greatest Challenges. UK Cambridge: Cambridge University Press. doi: 10.1017/CBO9781139013857

19. Tanskanen A.O., Danielsbacka M. (2019). Intergenerational family Relations. An Evolutionary Social Science Approach. London: Routledge. doi: 10.4324/9781315107806

20. The Civil Law. (1937). Valdības Vēstnesis, 41. Retrieved from https://likumi.lv/ta/en/en/id/225418

21. Ungar M. (2008). Resilience across cultures. The British Journal of Social Work, 38(2), 218-235. doi: 10.1093/bjsw/bcl343

22. Ungar M. (2011). Social Ecologies and Their Contributions to Resilience. In M. Ungar (Ed.), The Social Ecology of Resilience. A Handbook of Theory and Practise, 13-31, Springer, New York, NY. doi: 10.1007/978-1-4614-0586-3_2

23. Ungar M., Liebenberg L. (2011). Assessing Resilience Across Cultures Using Mixed Methods: Construction of the Child and Youth Resilience Measure. Journal of Mixed Methods Research 5(2) 126 -149. doi: 10.1177/1558689811400607

24. Van Breda A.D. (2018). Reclaiming Resilience for Social Work: A Reply to Garrett. British Journal of Social Work, 49(1), 272-276. doi: 10.1093/bjsw/bcy010

25. Walsh F. (2016). Strengthening Family Resilience ( $3^{\text {rd }}$ ed.). New York: The Gouldford press.

26. Winokur M., Holtan A., Batchelder K.E. (2014). Kinship care for the safety, permanency, and well-being of children removed from the home for maltreatment: A Systematic Review. Oslo: The Campbell Collaboration. doi: 10.4073/csr.2014.2

27. Yin R.K. (1993). Application of Case Study Research. Beverly Hills and London: Sage+

28. Yıldırım F., Hablemitoğlu S. (2013). Ecological literacy for a sustainable future: proposal of an "Eco-sociologicl model". In V. Dislere (Ed.), The Proceedings of the International Scientific Conference Rural Environment. Education. Personality (REEP), 6. Jelgava: LLU, 46-50. Retrieved from https://llufb.llu.lv/conference/REEP/2013/Latvia-Univ-

Agricult_REEP_2013_ISSN_2255-808X-46-50.pdf 